\title{
Seed morphology and anatomy of Hypericum majus (A. Gray) Britton
}

\author{
Piotr Szkudlarz ${ }^{1 *}$, Zbigniew Celka $^{1}$, Stanisław Rosadziński\# \\ \& Maria Katarzyna Wojciechowicz ${ }^{2}$
}

\begin{abstract}
'Department of Plant Taxonomy, Faculty of Biology, Adam Mickiewicz University, Poznań, Uniwersytetu Poznańskiego 6, 61-614 Poznań, Poland; ORCID: PSz - http://orcid.org/0000-0002-4915-2721, ZC - http://orcid.org/0000-0002-5344-8939

${ }^{2}$ Department of General Botany, Faculty of Biology, Adam Mickiewicz University in Poznań, Uniwersytetu Poznańskiego 6, 61-614 Poznań, Poland; ORCID: MKW - http://orcid.org/0000-0001-9602-2535

*corresponding author (e-mail: szkudl@amu.edu.pl)
\end{abstract}

\begin{abstract}
Hypericum majus (A. Gray) Britton is an alien species for Europe. It originates from North America and, in recent years, has been spreading in Europe. Presently, this species is found in Germany, France, Italy, Bosnia and Herzegovina, and Belarus. In Poland, it was noted for the first time in 2017 in western part of the country. Thus far, no detailed morphology and anatomy of $H$. majus seeds based on light and electron microscopy studies has been presented. Considering the fact that seeds provide important taxonomical information and the discussed species has not been investigated in this respect, in this research, an attempt was made to broaden the present knowledge.

Investigations were conducted based on samples originating from three localities in Central Europe (Poland). The obtained results showed that $H$. majus seeds are very small - about $0.5 \mathrm{~mm}$ in length. In the SEM image, their surface is reticulate, typical of majority of species in this genus. Anatomical analysis showed that seed coat of matured seeds is very delicate, composed of two cell layers with strongly lignified walls.
\end{abstract}

Key words: carpology, greater Canada St. John's-wort, Hypericaceae, Poland, seed sculpture, seed coat

\section{Introduction}

The world flora of the genus Hypericum L. comprises, according to different sources, from about 370 to 520 species (Stevens 2007; Mabberley 2008; Nürk \& Blattner 2010; Crockett \& Robson 2011; The Plant List 2013; Hypericum online). In Europe, this genus is represented, depending on taxonomical approach, by 56-61 species (Mabberley 2008; Robson 2005), with 13 of these taxa observed in Poland to date (Mirek et al. 2002). The majority of species occurring in Poland are native taxa (H. elegans Stephan ex Willd., H. hirsutum L., H. humifusum L., H. maculatum Crantz, H. montanum L., H. perforatum L., H. pulchrum L., and H. tetrapterum $\mathrm{Fr}$.) or ephemerophytes (H. gymnanthum Engelm. \& A. Gray, H. mutilum L., and $H$. veronense Schrank). Furthermore, H. calycinum L. and $H$. hooke- rianum Wight \& Arn. were found in crops (Mirek et al. 2002; Jackowiak et al. 2013, 2017).

In the flora of Poland, a new, non-native species of Hypericum, which spreads also in many European countries, is H. majus (A. Gray) Britton (Nobis et al. 2018). This taxon originates from North America. It is a perennial plant that grows up to $0.7 \mathrm{~m}$ in height and develops one or several quadrangular stems. Leaf blades are lanceolate or elliptic (longitudinal) with entire margin. Inflorescence is apical and may consist of even 30 flowers. Flowers are stellate, $6-7 \mathrm{~mm}$ in diameter, petals golden-yellow $(3.5-6.5 \times 0.8-1.5 \mathrm{~mm})$. Stamens 12-21, ovary 1.5-2.0 $\times 0.8-1.0 \mathrm{~mm}$, ovoid to ellipsoid; styles 3 ; stigmas narrowly capitate (Hypericum online).

The floristic composition of $H$. majus phytocoenoses matches phytosociological preferences of this species in southern and western Europe (Bouchard 1954; Nezadal

\# co-author prepared this publication in cooperation with the Department of Plant Taxonomy 
1984; Prince \& Aniotsbehere 2012; Milanović 2018). In Poland, optimal habitats of $H$. majus comprise periodically exposed pond bottoms, water body margins and periodically flooded former gravel pits. It forms dense phytocoenoses that hinder the development of small terophytes from the Isoëto durieui-Juncetea bufonii class. Furthermore, locally, this species poses a threat to phytocoenoses from the Hydrocotylo-Baldellion alliance (e.g., Pilularietum globuliferae). In overgrown, unused ponds, H. majus was also found in the communities representing the Molinio-Arrhenatheretea, Phragmitetea australis and Scheuchzerio-Caricetea fuscae classes (Nobis et al. 2018). In western Poland, $H$. majus was observed in several ponds occurring within three active or abandoned fish farms and in a periodic pond at the bottom of the abandoned gravel pit. In total, the species was found in 5 localities in western Poland (Nobis et al. 2018).

Hypericum species occurring in Poland are mainly perennials, rarely bushes or annuals (among others, Zarzycki et al. 2002; Hypericum online). Their seeds are of high diagnostic value in systematics and paleobotany (Robson 1981; Hageman 1987; Meseguer \& Sanmartín 2012; Alonso et al. 2013). A particularly important feature is the sculpture of the seed coat and cell arrangement of its outer layer. However, only a relatively small number of Hypericum species have been studied so far in terms of seed morphology (Meseguer \& Sanmartín 2012; Alonso et al. 2013; Szkudlarz \& Celka 2016) and information about the anatomical structure of seeds in this genus has been also very limited (Szabes \& Morozowa 1991; Matzk et al. 2001; Szkudlarz 2014).

In Poland, all native Hypericum species were investigated in detail in terms of their seed morphology (Szkudlarz 2014; Szkudlarz \& Celka 2016) and in case of $H$. elegans also anatomically (Szkudlarz 2014). A new species $-H$. majus, which spreads in western Poland, has not been studied yet in this regard in Europe. Thus, the aim of this work was an analysis and detailed description of morphological and anatomical structure of the seed coat in H. majus.

\section{Material and methods}

Seeds for the study were obtained from herbarium specimens representing populations of $H$. majus distributed in western Poland (Table 1, Fig. 1). These specimens are deposited in the Herbarium of Department of Plant Taxonomy of Adam Mickiewicz University in Poznań (POZ) (Fig. 2).

Morphological structure was investigated based on the dry seed analysis using a stereomicroscope and scanning electron microscope (SEM). For SEM observations, 5 seeds were sampled and coated with gold. All morphological measurements were made using a stereomicroscope with NIS-Elements Microscope Imaging Software. SEM images were used in analysis of quantitative traits of the seed coat. In this work, we

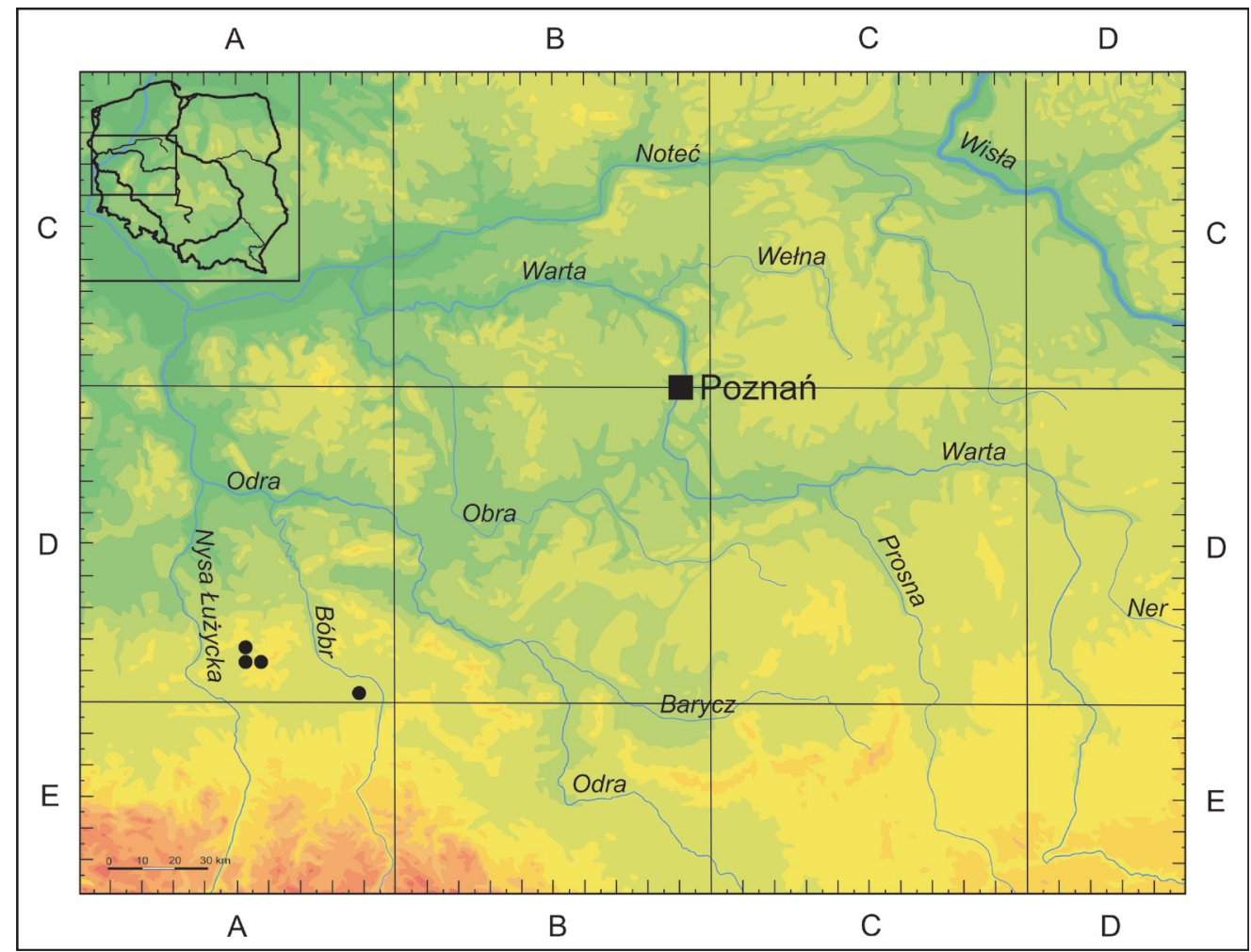

Fig. 1. Distribution of Hypericum majus in western Poland in the ATPOL grid squares of $5 \times 5 \mathrm{~km}$ 
Table 1. Origin of the examined seed samples of Hypericum majus

\begin{tabular}{|c|c|c|c|c|c|}
\hline Locality & $\begin{array}{l}\text { Geographic } \\
\text { coordinates }\end{array}$ & Habitat & ATPOL & Data zbioru & Collector \\
\hline $\begin{array}{l}\text { Rościce village, Żarskie } \\
\text { hills }\end{array}$ & $\begin{array}{l}51^{\circ} 36^{\prime} 24^{\prime \prime} \mathrm{N} \\
1^{\circ} 59^{\prime} 38^{\prime \prime} \mathrm{E}\end{array}$ & $\begin{array}{l}\text { alt. } 160 \mathrm{~m} \text {, in } 3 \text { ponds } \\
\text { on a fishing farm }\end{array}$ & AD8503 & 2 August 2017 & S. Rosadziński \\
\hline $\begin{array}{l}\text { Miłowice village, Żarskie } \\
\text { hills }\end{array}$ & $\begin{array}{l}51^{\circ} 36^{`} 5,37^{\prime \prime} \mathrm{N} \\
15^{\circ} 3^{`} 18,26^{\prime \prime} \mathrm{E}\end{array}$ & $\begin{array}{l}\text { alt. } 147 \mathrm{~m} \text {, in an } \\
\text { overgrowing pond }\end{array}$ & AD8504 & 3 August 2017 & S. Rosadziński \\
\hline $\begin{array}{l}\text { near Bobrowice village, } \\
\text { Dolnośląskie Forest }\end{array}$ & $\begin{array}{l}51^{\circ} 31^{\prime} 17^{\prime \prime} \mathrm{N} \\
15^{\circ} 31^{\prime} 30^{\prime \prime} \mathrm{E}\end{array}$ & $\begin{array}{l}\text { alt. } 137 \mathrm{~m} \text {, in an } \\
\text { overgrowing pond }\end{array}$ & AD9804 & 18 August 2017 & S. Rosadziński \\
\hline $\begin{array}{l}\text { near Boruszyn village, } \\
\text { Żarskie hills }\end{array}$ & $\begin{array}{l}51^{\circ} 36^{`} 41,01^{\prime \prime} \mathrm{N} \\
14^{\circ} 58^{`} 23,50^{\prime \prime} \mathrm{E}\end{array}$ & $\begin{array}{l}\text { alt. } 145 \mathrm{~m} \text {, in an } \\
\text { overgrowing pond }\end{array}$ & AD8503 & 16 November 2018 & S. Rosadziński \\
\hline $\begin{array}{l}\text { near Żary city, Żarskie } \\
\text { hills }\end{array}$ & $\begin{array}{l}51^{\circ} 37^{`} 43,04^{\prime \prime} \mathrm{N} \\
15^{\circ} 5^{\prime} 23,03^{\prime \prime} \mathrm{E}\end{array}$ & $\begin{array}{l}\text { alt. } 157 \mathrm{~m} \text {, in an } \\
\text { abandoned gravel pit }\end{array}$ & AD8503 & 16 November 2018 & S. Rosadziński \\
\hline
\end{tabular}

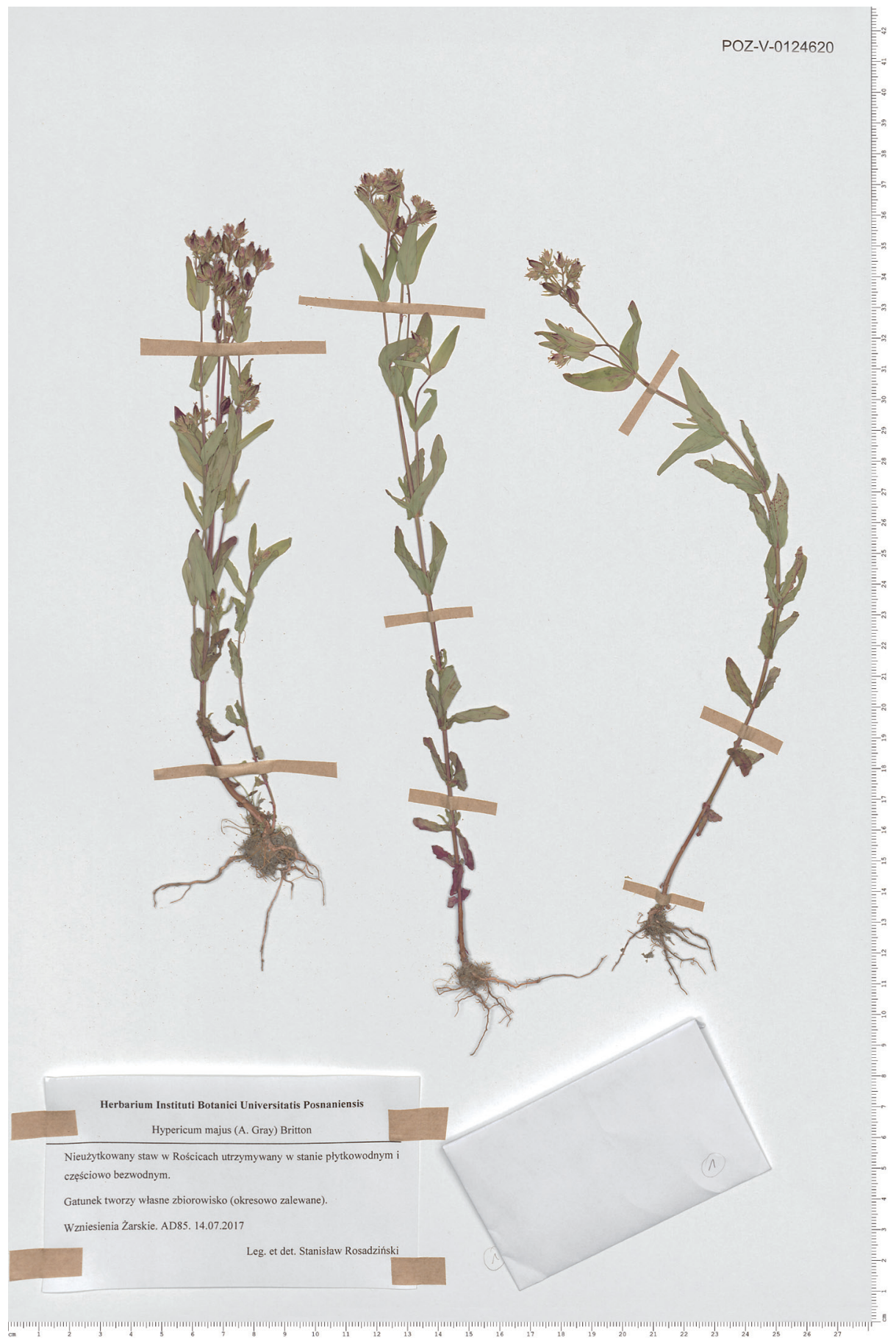

Fig. 2. Herbarium voucher of Hypericum majus from herbarium of the Department of Plant Taxonomy, Adam Mickiewicz University in Poznań (POZ) 
followed terminology widely used in the studies on seed morphology (Robson 1981; Bojňanský \& Fargašová 2007; Meseguer \& Sanmartín 2012).

To investigate the seed anatomical structure, material was subjected to a microtechnique procedure. Seeds were placed in the mixture of $2 \%$ solutions of glutaraldehyde and paraformaldehyde, then, they were kept for $1 \mathrm{~h}$ in vacuum chamber $(0.2 \mathrm{~atm})$ and, next, in fridge $\left(4^{\circ} \mathrm{C}\right)$ overnight. Fixed seeds were three times rinsed in $0.05 \mathrm{M}$ cacodylate buffer and dehydrated in the series of ethanol solutions with increasing concentration $(5,10,30,50,70,80,90,96$ and 100\%). To prepare microscopic slides, Technovit 7100 acrylic resin was used (Heraeus Kulzer Gmbh, Wahrheim, Germany) as an embedding medium. Slices of $4 \mu \mathrm{m}$ in thickness were stained with $0.05 \%$ solution of toluidine blue prepared in $1 \%$ sodium tetraborate. Additionally, seeds were stained with methylene blue-azure II and basic fuchsine prepared for the staining of epoxy-embedded tissue sections (Humphrey \& Pitmann 1974). Slides were analysed under the AxioScopeA1 microscope.

Lignin detection in the walls of seed coat cells was conducted under the AxioScopeA1 microscope with equipped Colibri 4. Unstained microscopic slides were observed using excitation light of $485 \mathrm{~nm}$. For this wavelength, autofluorescence of lignin shows up as green light emission within visible spectrum.

Photographic documentation of all slides was made using the AxioCam MRc5 digital camera (Carl Zeiss GmbH, Jena, Germany).

\section{Results}

\subsection{Morphological structure}

The studied seeds of $H$. majus are elongated, cylindrical, rounded at both ends with slightly marked beaks (Figs. 3-4). Their length is about $500 \mu \mathrm{m}$, while width about $200 \mu \mathrm{m}$. Seeds are slightly curved and

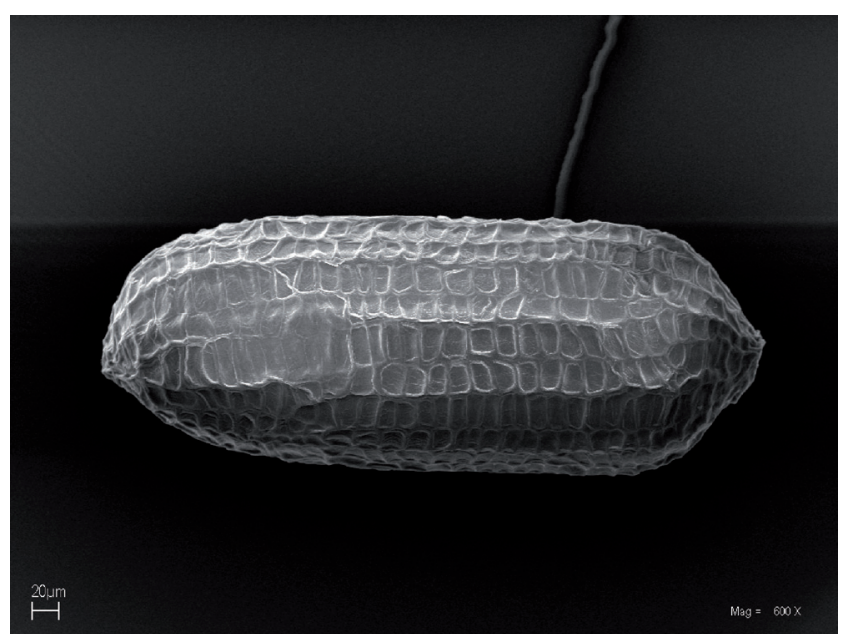

Fig. 3. Hypericum majus, seed (SEM)

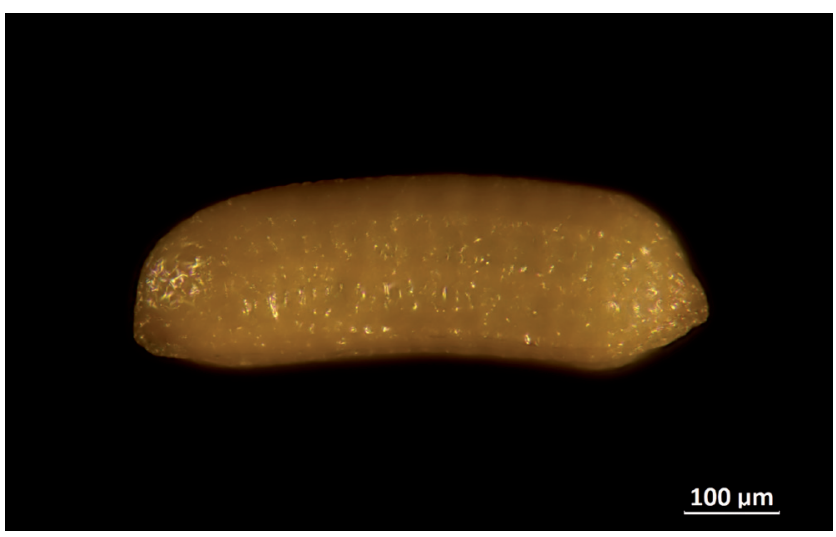

Fig. 4. Hypericum majus, seed (LM)

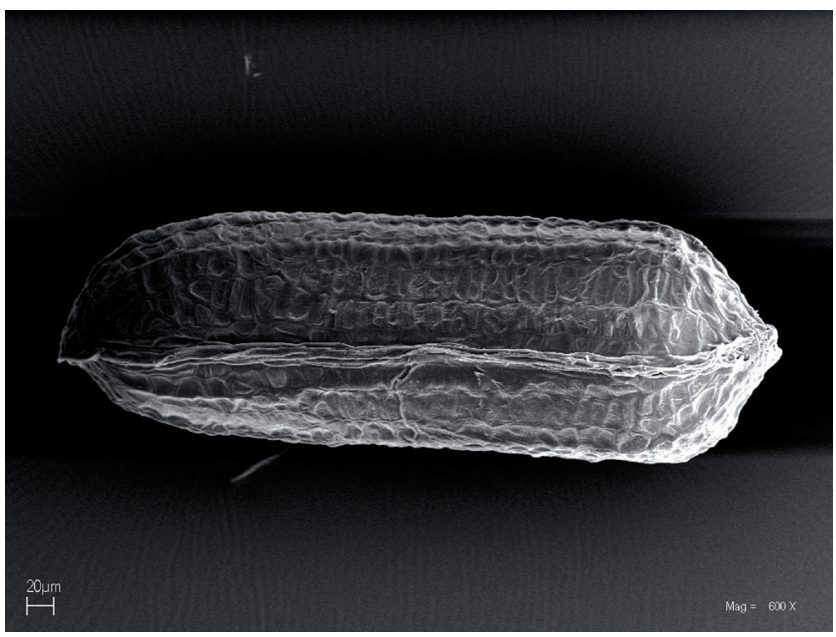

Fig. 5. Hypericum majus, seed (SEM), an abdominal view

there is a narrow, longitudinal scar after funiculus on the incurved side (Fig. 4-5). Under a light microscope, their surface is lustrous. Seeds are light brown (honey shade) in colour (Fig. 3). Under a SEM microscope, the surface is indistinctly reticulate, epidermal cells of the testa are polygonal (with 5-7 angles), distinctly wider than longer relative to the seed longitudinal axis (Fig. 6).

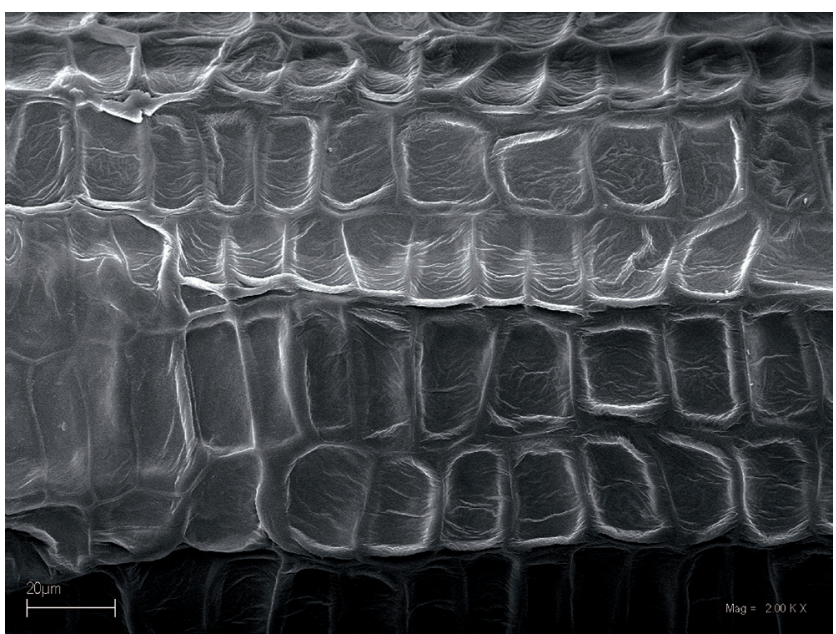

Fig. 6. Hypericum majus, surface of the seed coat (SEM) 


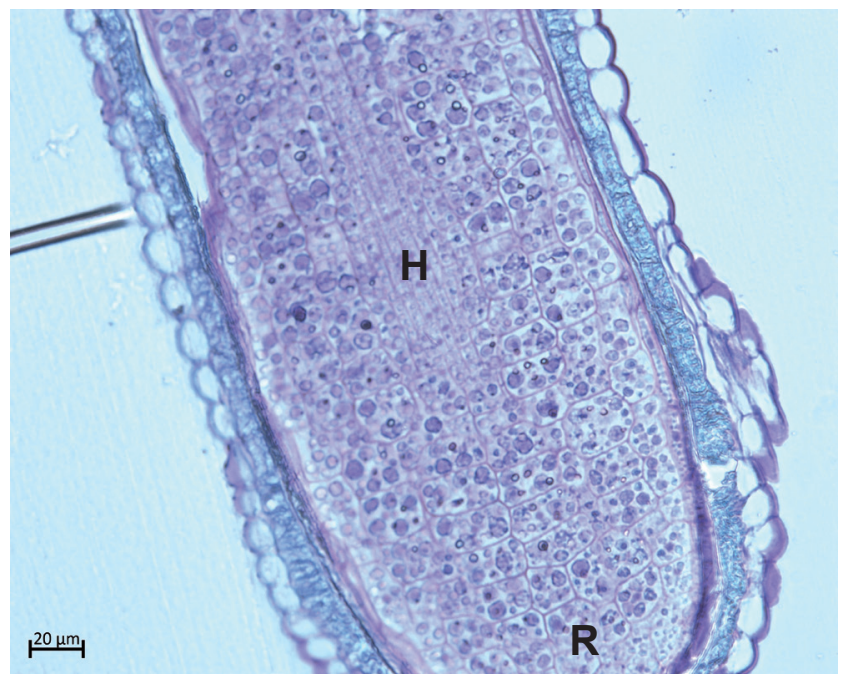

Fig. 7. Hypericum majus, longitudinal section across a mature seed (LM) showing a fragment of the seed coat with the outer and inner layers and embryo cells in the area of the hypocotyl $(\mathrm{H})$ and radicle $(\mathrm{R})$

\subsection{Anatomical structure}

Two layers of cells can be usually distinguished in the coat structure of mature seeds, although in some places, the remains of additional, subepidermal layer may be visible (Fig. 7). The outer layer, originating from the epidermis of the testa, is composed of thinwall cells, with a greater width than length, and with straight radial walls. The cell shape of this layer is shows the SEM image (Fig. 6). In histological slides (longitudinal sections), the outer wall of these cells, convex on the outside, is distinctly thicker from radial walls and periclinal inner walls (Fig. 8). In mature dry seeds, the outer wall of the cells subsides, which results in characteristic reticulate surface.

The second layer of cells that make the seed coat of mature seeds has sclerenchymatous characteristics. It is

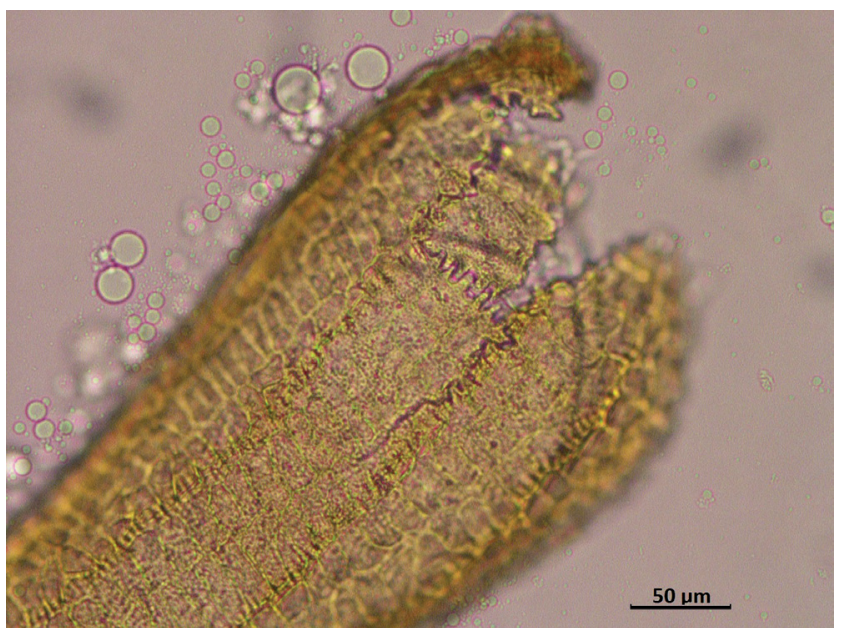

Fig. 9. Hypericum majus, surface view of the sclerenchyma layer (LM)

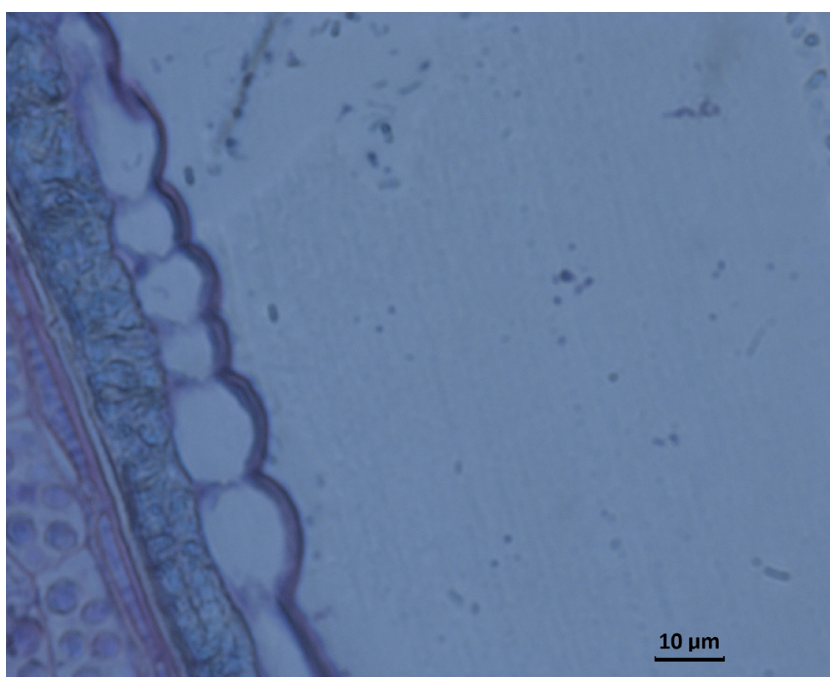

Fig. 8. Hypericum majus, fragment of the testa in the longitudinal section (LM), visible thickenings of the outer walls in the first cell layer

composed of isodiametric cells with highly thickened cell walls and numerous simple pits. Radial walls are strongly wavy (Figs. 9-10). The surface of these cells is visible after the removal of the outer layer. Analysis of histological slides under a fluorescent microscope showed that lignin is present in the cell walls of both layers (Fig. 11). The remaining layers of integument cells are subject to compression and do not contribute to the seed coat structure.

Almost an entire interior of $H$. majus seeds is occupied by an embryo. The embryo is straight, with welldeveloped cotyledons. The cotyledons constitute 1/5 of the embryo length. A highly elongated hypocotyl connects shoot and root poles. The entire embryo is surrounded by 2 layers of endosperm cells. Longitudinal sections of the embryo show 3 distinct areas of tissue differentiation. The first outer layer is protoderm, then

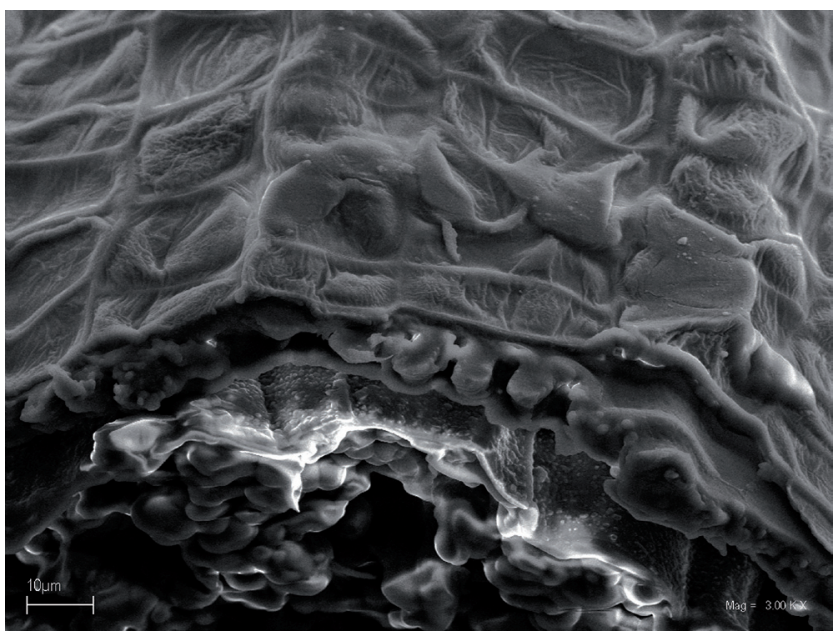

Fig. 10. Hypericum majus, the broken seed coat showing the wavy characteristics of walls in the sclerenchyma layer (SEM) 


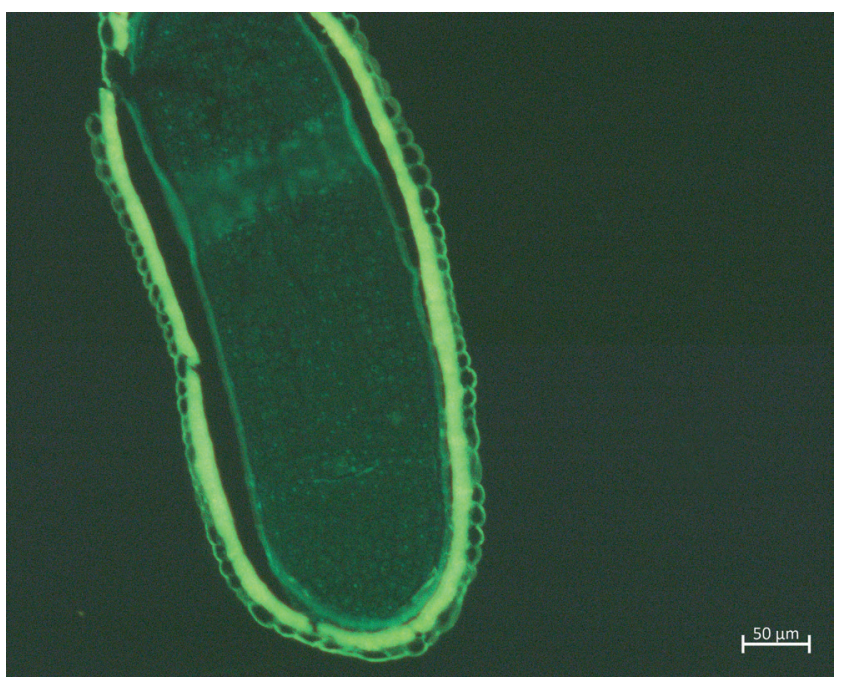

Fig. 11. Hypericum majus, longitudinal section (fluorescence microscope)

procortex, while in the middle, in the embryo axis, there is a zone of procambial differentiation (Fig. 12). The cells of the hypocotyl and endosperm contain numerous deposits of reserve materials (Fig. 13).

\section{Discussion}

In Poland, H. majus is the third (besides H. mutilum and $H$. gymnanthum) representative of the section Trigynobrathys (Y. Kimura) N. Robson, subsection Knifa (Adans.) N. Robson (Robson 1990; Hypericum online). H. majus seeds are small, even when compared to the seeds of other Hypericum species. The seed coat

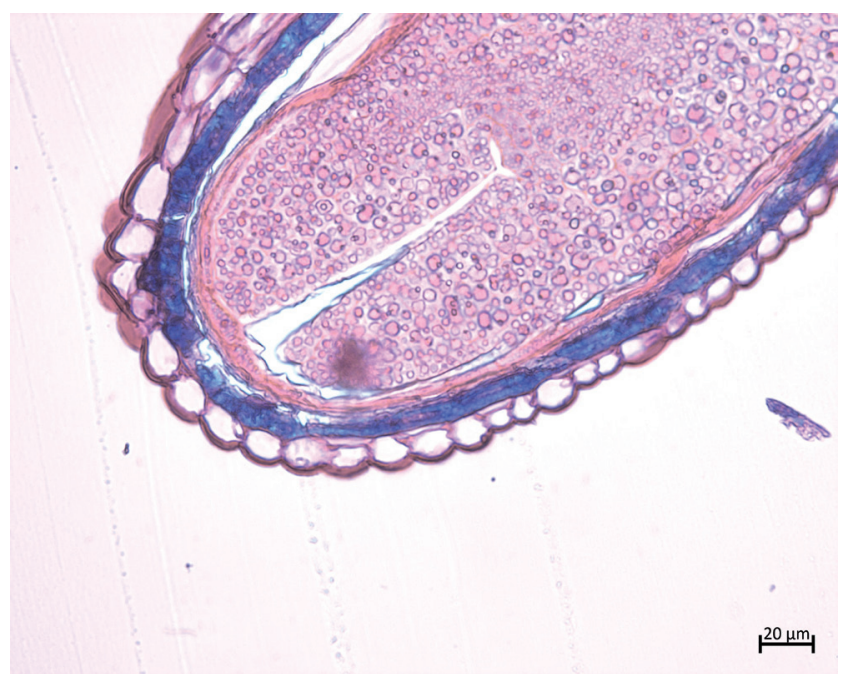

Fig. 13. Hypericum majus, longitudinal section across the mature seed (LM), the microscopic slide stained with the Humphrey and Pittman method (1974), visible numerous deposits of reserve materials in the embryo cells

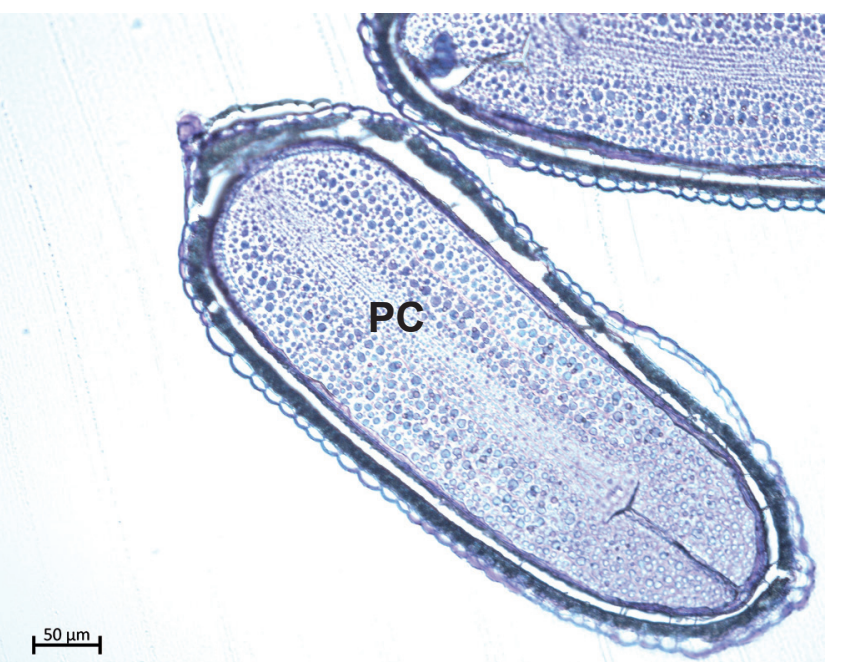

Fig. 12. Hypericum majus, longitudinal section accross the mature seed (LM) showing two cotyledons in the embryo and the zone of procambial differentiation $(\mathrm{PC})$

of mature seeds is very delicate, and its structure is similar to the seed coat in H. elegans seeds (Szkudlarz 2014).

Many studies indicate that Hypericum seeds develop from anatropous, tenuinucellate ovules with two integuments (Netolitzky 1926; Corner 1976; Sokołowskaja 1983; Szabes \& Morozova 1991). The outer integument is composed of two, while the inner integument of two or more cell layers (Corner 1976; Szabes \& Morozova 1991). The previous studies showed that the seed coat of mature $H$. majus seeds consists of two cell layers. The outer, composed of thin-wall cells, and the innersclerenchymatous, composed of thick-wall cells.

Following other authors (Corner 1976; Szabes \& Morozova 1991), it may be accepted that the outer layer originates from the epidermis of the testa, while other layers disappear during the seed maturation. Similarly, the sclerenchyma layer develops from the epidermis of the tegmen, while other layers disappear during the seed development. This layer is composed of cells with highly wavy radial walls, similarly like in other species of the genus (Netolitzky 1926; Corner 1976; Szkudlarz 2014). Additionally, in mature seeds, no deposits of any brown substances (tannins) have been observed in the epidermis of the testa, contrary to the reports of some authors (Ohlendorf 1907).

Acknowledgments. We sincerely thank the staff of Electron Microscopy Laboratory, Faculty of Biology, Adam Mickiewicz University in Poznań for the fine SEM work.

\section{Author Contributions}

Research concept and design: P. Szkudlarz, Z. Celka Acquisition and/or assembly of data: P. Szkudlarz, S. Rosadziński, M. K. Wojciechowicz 
Data analysis and interpretation: P. Szkudlarz, S. Rosadziński, M. K. Wojciechowicz

Drafting the article: P. Szkudlarz, S. Rosadziński, M. K. Wojciechowicz, Z. Celka
Critical revision: P. Szkudlarz, M. K. Wojciechowicz, Z. Celka

Final approval: P. Szkudlarz, Z. Celka

\section{References}

Alonso M. A., Agulló J. C., Villar J. L., Juan A. \& CRespo M. B. 2013. Taxonomic relationships in the Hypericum ericoides aggregate (H. sect. Coridium, Hypericaceae). Ann. Bot. Fennici 50: 195-207.

BoJNANSKÝ V. \& FARGAŠOVÁ A. 2007. Atlas of seeds and fruits of Central and East European Flora. The Carpatian Mountains Region. 1025 pp. Springer, Dordrecht.

Bouchard J. 1954. Un Hypericum nouveau pour la flore de France [A new Hypericum for the flora of France]. Bulletin de la Société Botanique de France 101(7-9): 351-354 (in French).

Corner E. J. H. 1976. The Seeds of Dicotyledons, 1, 331 pp. Cambridge University Press, Cambridge.

Crockett S. \& Robson N. 2011. Taxonomy and Chemotaxonomy of the Genus Hypericum. Medicinal and Aromatic Plant Science and Biotechnology 5 (Special Issue 1): 1-13.

Hageman I. 1987. On subspecific taxa of Hypericum empetrifolium (Hypericaceae) from Crete. Pl. Syst. Evol. 155: 165-187.

Humphrey C. D. \& Pittman F. E. 1974. A simple methylene blue-azure II-basic fuchsin stain for epoxy- embedded tissue sections. Stain Technology 49: 9-14.

HyPERICUM ONLINE. A site dedicated to Hypericum - The St John's Worts. http://hypericum.myspecies.info/ (accessed 31 July 2019).

Jackowiak B., Celka Z., Chmiel J., Latowski K. \& Żukowski W. 2013. Checklist of the vascular flora of Wielkopolska (Poland): native species and naturalized alien species. Biodiv. Res. Conserv. 31: 9-96.

JaCkowiak B., CelKa Z., Chmiel J., Latowski K. \& ŻUKowski W. 2017. Checklist of the vascular flora of Wielkopolska (Poland): casual alien species. Biodiv. Res. Conserv. 46: 35-55.

Mabberley D. J. 2008. Mabberley’s Plant-Book. A portable dictionary of plants their classification and uses. Ed. 3. xviii +1021 pp. Cambridge University Press, Cambridge.

Matzk F., Meister A., Brutovská R. \& Schubert I. 2001. Reconstruction of reproductive diversity in Hypericum perforatum $\mathrm{L}$. opens novel strategies to manage apomixis. The Plant Journal 26(3): 275-282.

Meseguer A. S. \& Sanmartín I. 2012. Paleobiology of the genus Hypericum (Hypericaceae): a survey of the fossil record and its palaeogeographic implications Anales del Jardín Botánico de Madrid 69(1): 97-106

Milanović Đ., Maslo S. \& ŠArić Š. 2018. Four neophytes new for the flora of Bosnia and Herzegovina. Botanica Serbica 42(1): 139-146. DOI 10.5281/zenodo.1173570
Mirek Z., Piękoś-Mirkowa H., Zając A. \& Zając M. 2002. Flowering plants and pteridophytes of Poland. A checklist. In: Z. MireK (ed.). Biodiversity of Poland, 1, 442 pp. W. Szafer Institute of Botany, Polish Academy of Sciences, Kraków.

Netolitzky F. v. 1926. Anatomie der Angiospermen Samen. In: K. Linsbauer (ed.). Handbuch Der Pflanzenanatomie. Abt. II T. 2 Bd. X, 360 pp. Berlin.

Nezadal W. 1984. Wiederfund von Illecebrum verticillatum zusammen mit Radiola linoides, Juncus capitatus und Hypericum majus bei Grafenwohr/Opf. [Rediscovery of Illecebrum verticillatum with Radiola linoides, Juncus capitatus and Hypericum majus near Grafenwoehr (Oberpfalz)]. Berichte der Bayerischen Botanischen Gesellschaft zur Erforschung der heimischen Flora 55: 67-71 (in German).

Nobis M., Klichowska E., Terlevića A., Wróbel A., Erst A., Hrivnák R., Ebel A. L., Tikhomirov V. N., Byalt V. V., Gudkova P. D, Király G., Kipriyanova L. M., Olonova M., Piwowarczyk R., Pliszko A., Rosadziński S., Seregin L. P., Honcharenko V., Marciniuk J., Marciniuk P., Oklejewicz K., Wolanin M., Batlai O., Bubíková K., Choi H.-J., Dzhus M. A., Kochjarová J., Molnár A. V., Nobis A., Nowak A., OŤAhelová H., Óvári M., Shimko I. I., Shukherdorj B., Sramkó G., Troshkina V. I., Verkhozina A. V., Wang W., Xiang K. \& Zykova E. V. 2018. Contribution to the flora of Asian and European countries: new national and regional vascular plant records, 8. Botany Letters 165(2): 200-222, DOI: 10.1080/23818107.2017.1415817

NÜRK N. M. \& Blattner F. R. 2010. Cladistic analysis of morphological characters in Hypericum (Hypericaceae). Taxon 59: 1495-1507.

Ohlendorf O. 1907. Beiträge zur Anatomie und Biologie der Fruchte und Samen einheimischer Wasser- und Sumpfpflanzen. Jahresbericht des Naturwissenschaftlichen Vereins zu Osnabrück 16: 34-137.

Prince G. \& Aniotsbehere J. C. 2012. Une espèce nouvelle de plante pour la Gironde et l'Aquitaine: Hypericum majus (A. Gray) Britton [A new species of plant for Gironde and Aquitaine: Hypericum majus (A. Gray) Britton]. Bulletin de la Société Linnéenne de Bordeaux 40(3): 301-304 (in French).

Robson N. K. B. 1981. Studies in the genus Hypericum L. (Guttiferae) 2. Characters of the genus. Bull. Br. Mus. nat. Hist. (Bot.) 8(2): 55-226.

Robson N. K. B. 1990. Studies in the genus Hypericum L. (Guttiferae) 8. Sections 29. Brathys (part 2) and 30. Trigynobrathys. Bull. Br. Mus. nat. Hist. (Bot.) 20(1): 1-151. 
Robson N. K. B. 2005. Hypericum L. In: T. G. Tutin, V. H. Heywood, N. A. Burges, D. M. Moore, D. H. Valentine, S. M. Walters, D. A. Webb (eds.). Flora Europaea, vol. 2 Rosaceae to Umbelliferae, 261-269 pp. Cambridge University Press, Cambridge.

Stevens P. F 2007. Hypericaceae. In: K. Kubitzki (ed.). The Families and Genera of Vascular Plants, 9, pp. 194201. Springer Verlag Berlin-Heidelberg.

Szkudlarz P. 2014. Seed morphology and anatomy of Hypericum elegans Steph. ex Willd. Biodiv. Res. Conserv. 35: $15-18$.

Szkudlarz P., Celka Z. 2016. Morphological characters of the seed coat in selected species of the genus Hyperi- cum L. and their taxonomic value Biodiv. Res. Conserv. 44: 1-9.

Szabes L. A. \& Morozova A. A. 1991. Clusiaceae. In: A. L. TAKHTAJAN (ed.). Sravnitielnaya anatomiya semyan 3: 209-215. Sankt Petersburg.

The Plant List 2013. Version 1.1. Published on the Internet; http://www.theplantlist.org/ (accessed 31 July 2019).

Zarzycki K., Trzcińska-Tacik H., RóŻańSKi W., Szeląg Z., WoŁeK J. \& KorzeniaK U. 2002. Ecological indicator values of vascular plants of Poland. In: Z. MireK (ed.). Biodiversity of Poland, 2, 183 pp. W. Szafer Institute of Botany, Polish Academy of Sciences, Kraków. 